\title{
POKOLENIE POMOCNIKÓW ARTYLERII. HABERMAS, RATZINGER, LUHMANN I NIEMIECKIE SPORY
}

Karolina Wigura

Uniwersytet Warszawski

\section{/// Wprowadzenie}

Istnieja niezliczone sposoby ucieczki przed nazistowską przeszłościa stwierdza Joachim Fest pod koniec swojej autobiografii i dodaje: dobrym przykładem jest historia jednego z najbardziej liczących się intelektualistów naszego kraju. Intelektualista ten w czasie panowania narodowego socjalizmu był bardzo zaangażowanym dowódcą młodzieży ${ }^{1}$, głęboko oddanym Führerowi i niezłomnie wierzącym w zwycięstwo. Kilkadziesiąt lat później, podczas przyjęcia urodzinowego, jeden z dawnych kolegów z Hitlerjugend pokazał owemu intelektualiście napisane przez niego w czasach III Rzeszy wyznanie wierności Hitlerowi. Ów zaś, nie przyjrzawszy się nawet dokładnie dokumentowi, wyrwał koledze papier z ręki, zmią i... połknął (Fest 2006: 336).

Autobiografia Festa została wydana po jego śmierci, w 2006 r. Wkrótce potem przytoczona historia na moment doprowadziła niemiecką sferę publiczną do stanu wrzenia. W ,jednym z najbardziej liczących się intelektualistów naszego kraju" natychmiast rozpoznano Jürgena Habermasa. $\mathrm{Na}$ okładce prestiżowego miesięcznika "Cicero" umieszczono wielki napis „Habermas zapomina!”, a obok pop-artowy portret filozofa ${ }^{2}$. W środku, pod tytułem „Czy Habermas połknął prawdę?”, wydrukowano rozwinięta wersję powyższej historii, pióra konserwatywnego dziennikarza Jürgena Busche'a (Busche 2006). Autor Teorii dziatania komunikacyjnego, nie zwlekając, napisał do „Cicero” pełen oburzenia list, zarzucając redaktorom, że zadenuncjowano go w najgorszym stylu (Habermas 2006) ${ }^{3}$.

\footnotetext{
${ }^{1}$ Hitlerjugendführer, w skrócie HJ-führer.

2 Strona tytułowa „Cicero” z 26 listopada 2006 r.

${ }^{3}$ Habermas wspomina również czasy Hitlerjugend w jednej ze swojej książek. Patrz: Habermas 1981: 511-512.
} 
Historia była jeszcze przez krótki czas na ustach wszystkich, aż wreszcie zdementował ją naoczny świadek. Była to ta sama osoba, która rzekomo miała podać Habermasowi nieszczęsny dokument podczas przyjęcia w latach 80. - historyk z Bielefeldu, Hans Ulrich Wehler. „Habermas niczego nie połknął” - pisał na łamach tygodnika „Die Zeit” Wehler i dodawał, że filozof nie był nigdy dowódcą młodzieży. W Hitlerjugend szkolono go na felczera i sanitariusza. „Zrobienie z czternastolatka, który chciał zostać lekarzem, oddanego każdym włóknem swojej osobowości fanatyka, to czysta perfidia" - dodawał emerytowany profesor (Wehler 2006).

Później argumentowano, że Fest, pisząc swoją autobiografię, był już ciężko chory i że nie zdążył zweryfikować wielu zawartych w niej informacji (Wenzel 2006). Inni sugerowali, że była to próba zemsty na lewicowym filozofie ze strony konserwatywnego historyka, który przed laty zajął przeciwne mu stanowisko podczas słynnej Historikerstreit (Pinzani 2007: 12, zob. także Rathgeb 2005; Jabłkowska, Żyliński 2008). Nie wchodząc w rozważania, która z wersji jest bliższa prawdy, z historii tej z cała pewnością można wyciagnąć wniosek, że informacje dotyczące Jürgena Habermasa, a także różne wypowiedzi - zarówno jego, jak i na jego temat - budzą w Niemczech duże emocje i bywaja przyczynkami do całych debat. Dowodem na to, że zainteresowanie nie maleje, jest choćby okładka, jaka przygotował tygodnik „Die Zeit” z okazji jego ubiegłorocznych osiemdziesiątych urodzin. Na samym jej środku umieszczono ogromne zdjęcie filozofa na tle rzędów książek, podpisane słowami „Weltmacht Habermas”, co tłumaczyć można jako „Światowa potęga Habermas” 4.

Jednak ogromne zainteresowanie i silne emocje dotyczą nie tylko Habermasa. O podobnych reakcjach można mówić w przypadku jego rówieśników (przypomnijmy: autor Praysz̨łości natury ludzkiej urodził się w 1929 r.). Gdy Joseph Ratzinger (rocznik 1927) został wybrany na papieża, całe Niemcy spierały się, czy „pancerny kardynał”, zwany zreszta także „katolickim Habermasem z Rzymu” (sic!) (Kissler 2005: 147) będzie dobrze spełniał posługę Piotrowa. Dwaj inni przedstawiciele tego samego pokolenia, Günter Grass i Martin Walser (obaj z rocznika 1927), nie raz wstrzasali opinia publiczna. W historii wielkich debat publicznych Republiki Federalnej znajdziemy dysputy nazwane od nazwiska każdego z nich (Rathgeb 2005; Jabłkowska, Żyliński 2008). Z kolei Niklas Luhmann (również rocznik 1927) stoczył z Habermasem jedną z najważniejszych debat $\mathrm{w}$ najnowszej niemieckiej - jeśli nie światowej - historii socjologii

\footnotetext{
${ }^{4}$ Strona tytułowa „Die Zeit”, nr 25 z 10 czerwca 2009 r.
} 
(Habermas, Luhmann 1971). Wśród socjologów nie sposób nie wspomnieć także o Ralfie Dahrendorfie (rocznik 1929).

Do tego samego pokolenia należą również inne osoby, dziś uznawane za wybitne osobowości nie tylko w Niemczech. Są wśród nich między innymi: sekretarz generalny NATO w latach 1986-1989 Wolfgang Altenburg (rocznik 1928); ekonomista i prezes Bundesbanku w latach 19801991 Karl Otto Pöhl (rocznik 1928); polityk, minister spraw zagranicznych i wicekanclerz RFN w latach 1974-1992, Hans Dietrich Genscher (rocznik 1927); prezydent RFN w latach 1999-2004 Johannes Rau (rocznik 1931); pisarz, poeta i tłumacz Hans Magnus Enzensberger (rocznik 1929) czy pisarka Christa Wolf (rocznik 1929).

Te oraz wiele innych osób z pokolenia późnych lat 20. XX stulecia są dziś w poważnym wieku, a część już nie żyje. Jednak, by użyć słów Heinza Budego, socjologa specjalizującego się w badaniach nad społeczeństwem niemieckim, niektórzy z nich „wciąż sa jeszcze przy władzy” (Bude 1987: 9). Wydaje się, że jego słowa, mimo upływu wielu lat, są nadal uzasadnione. Nie tylko dlatego, że osoby te, wciąż zajmujące ważne społecznie stanowiska, stanowią wdzięczny temat do badań, jako przykłady szczególnego typu powojennych karier zawodowych („Udało im się - pisał Bude - synom pomocników na budowie, kelnerów, rzemieślników, szefów personelu. Zostali profesora-mi i rozpoznawalnymi na całym świecie osobistościami” [Bude 1987: 9]). Także dlatego, że całe to pokolenie, a nie tylko najbardziej znani jego reprezentanci, było jednym $z$ najważniejszych, najpierw dla zbudowania, a następnie dla rozwoju modelu nowoczesnej Republiki Federalnej - takiej, jaką znamy dziś (Bude 1987: 10).

Niniejszy artykuł poświęcony jest po części całemu pokoleniu rówieśników Habermasa, Grassa i Luhmanna, po części zaś - wybitnym jednostkom, które się z niego wywodzą. W pierwszej części tekstu przedstawię ogólną charakterystykę tej generacji. W drugiej - jako rodzaj case study portretu intelektualnego - zaprezentuję pokrótce dwie ważne dyskusje: między Jürgenem Habermasem a Niklasem Luhmannem oraz między Jürgenem Habermasem a Josephem Ratzingerem.

\section{/// Pokolenie pomocników artylerii}

Pokolenie Habermasa, Ratzingera i Luhmanna określa się w Niemczech dwojako. Po pierwsze, nazywa się je „Flakhelfer-Generation” - co dosłownie znaczy „pomocnicy Luftwaffe”, czy też „pomocnicy artylerii” (FlaK to skrót od Fliegerabwehrkanone - artyleria przeciwlotnicza). Chodzi o młodzież, urodzoną między 1926 a 1930 r., którą przed osiagnięciem pełnoletności 
(między 15 a 17 rokiem życia) wcielono do Wehrmachtu. Młodzi ludzie byli zaprzysięgani następującą formułą: „obiecuję, że jako pomocnik Luftwaffe będę bezustannie wypełniać mój obowiązek, wiernie i posłusznie, dzielnie i zawsze gotowy do walki, jak przystało na członka Hitlerjugend" (Schätz 1974: 30) ${ }^{5}$. Używając słów Heinza Budego, wyciagano ich wprost ze szkolnej ławki, by przymusowo uczynić z nich „ostatnich bohaterów Führera” (Bude 1987: 9). „W sposób odpowiadający ich siłom” mieli „pomagać w ochronie powietrznej ojczyzny” (Schätz 1974: 29), zasilić słabnąca armię Hitlera w jej beznadziejnych próbach walki pod koniec II wojny światowej. W 1945 r. dochodziło do tego, że w niektórych miejscach stanowili oni $45 \%$ składu oddziałów Luftwaffe.

Po drugie, nazywa się je „pokoleniem '45”, od określenia, jakie nadał swojej generacji profesor muzykologii i wieloletni redaktor „Süddeutsche Zeitung” Joachim Kaiser (Fest 1983). Nazwa ta podkreśla graniczność roli, jaką odegrał w ich życiu koniec wojny. Wielu z nich, zanim osiaggnęło pełnoletność, przeżyło dojście Hitlera do władzy i rosnący terror w latach 30., potem wojnę - a gdy doszli niemal do pełnoletności (mieli między 15 a 19 lat), nastapił rok 1945: „Upadek”, „Godzina zero”. Dość szybko ze względu na wiek - wypuszczani z obozów jenieckich, wracali do szczątków własnych miast, kulturowego niebytu Niemiec. Wielu wróciło od razu po wojnie do szkoły, by zdać maturę. Wnioskiem, jaki przeważająca większość z nich wyciąnnęła z osobistej sytuacji - pisze Bude - była decyzja o własnej karierze (Bude 1987: 9). „Życie toczy się dalej” - powtarzano wówczas w Niemczech. W środku lat 50. przyszły pierwsze sukcesy, dostawali pierwsze liczące się posady, nagradzano ich wiedzę. Byli ucieleśnieniem tego, co odradzająca się niemiecka tożsamość pragnęła powtarzać dekadę po wojnie: „znów jesteśmy kimś” (Bude 1987: 10). W latach 80. nie tylko piastowali wysokie funkcje w społeczeństwie, ale też zaczęto uważać ich za autorytety - intelektualne, społeczne, moralne. Najbardziej znani z nich odegrali zasadniczą rolę w być może najgorętszej debacie o wojennej przeszłości Niemiec - wspomnianej Historikerstreit w drugiej połowie lat 80. (Augstein 1995). Potem zyskiwali coraz większą sławę - dostawali liczne wyróżnienia, zajmowali coraz bardziej eksponowane stanowiska. Dziś ich urodziny obchodzone są hucznie przez ogólnoniemiecką ambitną prasę.

W jaki sposób pokolenie to różni się od swoich poprzedników i od pokoleń następnych? Wymieńmy te elementy, które dla umiejscowienia „pokolenia '45” są szczególnie ważne. W Niemczech umownie mówi się o pokoleniu Ruchu Młodych (Generation der Jugendbewegung, roczniki

\footnotetext{
${ }^{5}$ Dobór cytatów z Schätza za Heinzem Budem. Wszystkie cytaty w tłumaczeniu autorki.
} 
1896-1913), pokoleniu II wojny światowej (Kriegsgeneration des Zweiten Weltkriegs, roczniki 1913-1925), po których przychodzi właśnie pokolenie pomocników artylerii. Kolejna jest generacja Ruchu Studenckiego (Generation der Studentenbewegung, roczniki zaraz po II wojnie światowej) polskiemu czytelnikowi być może najbardziej znana dzięki jej głośnemu sprzeciwowi wobec milczenia na temat zbrodni nazizmu (Bude 1987; Schmidbauer 2009; Ustorf 2008).

Przekonany o aplikowalności Mannheimowskiego podziału na klasy i pokolenia, które mają reprezentować swoiste sposoby działania, myślenia i odczuwania (Mannheim 1964), do społeczeństwa niemieckiego, Heinz Bude tłumaczy różnice między niemieckim pokoleniem ' 45 a bezpośrednio poprzedzającym je pokoleniem wojennym, odwołując się do literatury pięknej. Każde z pokoleń różni się od poprzedzających i kolejnych zarówno, gdy chodzi o życiowe doświadczenia, jak zainteresowania - pisze Bude. „Literatura całkowitego zniszczenia” (Kahlschlagliteratur), jak określił ja Wolfgang Weyrauch (Weyrauch 1989: 175-183), pisana przede wszystkim przez Wolfganga Borcherta, Güntera Eicha, Wolfdietricha Schnurrego czy Wernera Stelly, charakteryzuje się stylem odmiennym, niż ta autorstwa Güntera Grassa, Hansa Magnusa Enzensbergera, Martina Walsera czy Ingeborg Bachman. Pierwsi pisali o powrotach do domu śmiertelnie wyczerpanych, obarczonych wojenną winą ludzi, próbujących dokonać bilansu strat. Pod względem stylistycznym dominują wtedy krótkie, często urywane zdania w pierwszej osobie, lakoniczne dialogi. Z kolei w piśmiennictwie, które pod koniec lat 50. XX w. określane było jako „nowa literatura niemiecka”, dominuja opisy prób poradzenia sobie z nowymi warunkami życia, analiza rzeczywistości nowego państwa, jakim była Republika Federalna, wydobywanie spod powierzchni pozornej niepamięci pogrzebanych tam fragmentów przeszłości. Proza jest spokojniejsza, zdania dłuższe i klasycznie zbudowane (Bude 1987: 33).

„Flakhelfer-Generation” doczekało się również kilku poważnych opracowań. Zwrócimy tu uwagę na dwa wcześniejsze. Pierwszym jest Die skeptische Generation Helmuta Schelsky'ego, książka opublikowana w 1957 r. Drugim - Versuch über die Schwierigkeit, nein zu sagen Klausa Heinricha ${ }^{6}$.

\footnotetext{
${ }^{6}$ Można wymienić również wiele innych, ciekawych opracowań na temat Flakhelfer-Generation. Najobszerniejsza jest zapewne ksiażka Rolfa Schörkena Luftwaffenhelfer und Drittes Reich, warto jednak zwrócić uwagę również np. na Jugend der Nachkriegszeit Gerharda Baumerta oraz Schule und Jugend in einer ausgebombten Stadt Irmy Kuhr. W niniejszym artykule jednak będę głównie powoływała się na cytowaną już wyżej książkę Heinza Budego, jako jedyną, która omawia Flakhelfer-Generation pod kątem karier wyróżniających się jednostek pochodzących z tego pokolenia. Warto dodać, że artykuł niniejszy nie ma ambicji wyczerpującej rekonstrukcji socjologicznej tego pokolenia, ale charakterystykę wybranych z niego jednostek na tle tegoż pokolenia.
} 
Zdaniem Schelsky'ego sceptycyzm był najważniejszym praktycznym wnioskiem, który „pokolenie '45” wyciagnęło ze swoich młodzieńczych doświadczeń. Młodzież ta

została w najwcześniejszych latach zebrana, rozgrzana i przetrącona w imię ideologii totalitarnej. Jej najważniejszym doświadczeniem było, że polityczna wiara i zaangażowanie prowadzą do totalnego zniszczenia" (Schelsky 1957: 75) ${ }^{7}$.

Dlatego w pierwszych dziesięcioleciach po wojnie Flakhelferzy odwracaja się milcząco od polityki i silnego zaangażowania w sferę publiczną.

W tym czasie władzę w Republice Federalnej obejmuje pokolenie "Jugendbewegung", będące już wówczas w poważnym wieku i dlatego ironicznie zwane niekiedy „pokoleniem dziadków” (Bude 1987: 33-34). Jego przedstawiciele nie szczędzili młodym słów krytyki. Eduard Spranger pisał np.:

Utrata małych ojczyzn, utrata ojczyzny jako całości, rozerwanie rodzin, zagrożenie dla wolności osobistej i państwowej, gospodarka sterowana stekiem fikcji, głębokie zakłócenie porządku politycznego sprawami całkowicie bezproduktywnymi, jak fikcja partyjnych spotkań i kongresów - to wszystko są tylko najważniejsze punkty znacznie szerszego obrazu, ale wystarczające, by odtworzyć wizję świata, którego - jak sobie wyobrażam - nie mógłbym, mając zaledwie kilkanaście lat, znieść, nie popadając w ostateczna furię, z powodu mojej całkowitej bezsilności. Ale gdy bezsilność $\mathrm{i}$ cierpienie nie czynia produktywnym, gdy na te wyzwania nie znajduje się namiętna odpowiedź (Toynbee), w jakimże języku powinien do nas przemawiać los? Krótko mówiąc: brakuje mi nowej ideologii młodych, której źródłem byłyby otaczające nas sprawy i która byłaby zajęciem wobec tych spraw stanowiska (Spranger 1947, cyt. za: Bude 1987: 46).

Te gorzkie słowa znalazły wśród pokolenia pomocników artylerii odpowiedź:

Jesteśmy przedmiotem niezliczonych krytycznych wypowiedzi. Starsze pokolenie wierzy, że odkryło w młodych brak siły, której my nie umiemy - w swoim zabłąkaniu - odnaleźć. W nas jednak wywołuje to wyłącznie okrzyk: „zostawcie nas w spokoju! Nie chcemy niczego więcej słyszeć!”. Wcześniej było inaczej: z szeregów nowych pokoleń szły nowe impulsy, które zrywały z przodkami i rewolucjonizowały wszystkie społeczne obszary. Zdarzył się nawet czas, gdy nowe pokolenie okrzyknęło się hasłem „Sturm und Drang" 8 .

Schelsky nazywa pokolenie pomocników artylerii „ostrożnymi, ale odnoszącymi sukcesy młodymi ludźmi”, dla których najważniejsza była

\footnotetext{
${ }^{7}$ Wybór cytatów z Schelsky'ego i Heinricha za Heinzem Budem.

${ }^{8}$ Cytat z Suchende Jugend..., s. 10 (cyt. za: Bude 1987: 46).
} 
„funkcjonalna solidność” (Schelsky 1957: 381). Tłumaczy, że, widząc ruiny swojego państwa, zdecydowali się na zupełnie inną ścieżkę kariery niż poprzedzające ich pokolenia. Ich sukces miał być osiagany małymi krokami i służyć dokonaniom na miarę życia prywatnego, a nie obecności publicznej. Przez swoją niestrudzoną pracę u podstaw włożyli ogromny wysiłek w odbudowę kraju. W ten sposób „ostatni bohaterowie Führera” stali się podstawą odbudowy zachodnich Niemiec - więcej, ucieleśnieniem nowoczesnego modelu Republiki Federalnej. Ich sukces jednak, niezależnie od tego, jak byłby wielki, skrywa głęboko przez nich odczuwane poczucie oszukania, zmanipulowania, niepewności.

Zupełnie inaczej ocenia niemieckie pokolenie '45 Klaus Heinrich, gdy pisze w 1962 r. książkę Versuch über die Schwierigkeit, nein zu sagen. „Będę pisać o doświadczeniach pewnej ściśle ograniczonej sytuacji: o doświadczeniach z pewnym bardzo konkretnym rodzajem obojętności, która rozprzestrzeniła się w Niemczech jakiś czas po wojnie" - pisze (Heinrich 1985: 160). To, co Schelsky uważał za wycofanie wobec spraw społeczeństwa, Heinrich nazywa obojętnością. Protestuje przeciwko wizji Schelsky'ego, prezentującej „Flakhelferów” jako „bezpiecznych” konformistów, którzy, zamiast krzyczeć Jawobl!, powtarzają tylko „nie”. Jego zdaniem nie chodzi o „nie”, lecz o „nic”. „«Nic» jest bardziej puste i ogólniejsze, niż «Nie» - argumentuje. - Może zwrócić się przeciwko dowolnej rzeczy. Jest o wiele jeszcze mniej niezależne, niż «Nie»" (Heinrich 1985: 9). Osoby z pokolenia '45 nie są według niego „ostrożną młodzieżą, ale młodzieżą wybierająca ucieczkę. Ucieczkę przed rzeczywistością - w obojętność lub nawet brak tożsamości.

Bardzo ciekawe w tekście Heinricha jest odwołanie do wiersza Hansa Magnusa Enzensbergera: Schaum. Przytoczmy fragment tego wiersza, który ukazal się w 1960 r. w tomie Landessprache (Enzensberger 1960: 37-38).

urodziłem się ślepy, piana w oczach

ryczący z tęsknoty, nie widząc nieba

w czarny piątek, dziś przed trzydziestu laty $[\ldots]$

słuchaj!

kto woła grüßgott z piany?

kto zwie mnie nadzieja? i dlaczego nadzieja?

kto wyciaga do mnie lepką bratnią rękę? [...]

puszczajcie! puszczajcie! nie jestem jednym $z$ was

ani jednym $z$ nas: urodziłem się przypadkiem

pod spienionymi strugami wody, przypadkiem ryczący, 
szczerze mówiąc, samotny, bez braci, oślepiony,

w czarny piątek, w różanym bidecie ${ }^{9}$.

„Schaum” to słowo trudne do przetłumaczenia, oznaczające, zależnie od kontekstu, pianę, ślinę lub szumowiny. Enzensberger, rocznik 1929, dobrze wyraził poczucie istnienia pokolenia pomocników artylerii - komentuje Heinz Bude (Bude 1987: 52), a Heinrich dodaje:

Metafora „Schaum” nie oznacza przekonania do czegokolwiek lub siły. Wiara w moc życia, potrafiącą odnowić wszystko, wyczerpała się. „Schaum” nie jest ani jasną, ani ciemną metaforą. „Schaum” oznacza mętność, zamazanie (Heinrich 1985: 74).

Według Heinricha „Schaum” ma trzy zasadnicze właściwości. Nie sposób jej schwycić, jest marnej jakości, można się nią udusić. „Zbyt słodka" - pisze Enzensberger, na końcu wiersza znajdujemy zaś słowa o „różowej” czy „różanej” przyszłości. Słowa: loslassen! loslassen! ich bin keiner von euch und keiner von uns: ich bin zufällig geboren („puszczajcie! puszczajcie! nie jestem jednym z was ani jednym z nas: urodziłem się przypadkiem”) interpretuje Heinrich jako sprzeciw wobec utraty tożsamości przez zadławienie, przed którym istnieje tylko jeden ratunek: ucieczka w owej tożsamości brak (Heinrich 1985: 74).

Podobnie jak Heinrich, oceniał pokolenie '45 Helmut Thielicke, który pisał w 1955 r.: ,,to pokolenie nie dyskutowało, ale milczało. Udawało martwe, jak zwierzę w najwyższym poczuciu zagrożenia" (Heinrich 1985: 133). „Pozbawione tożsamości i mowy, troszczyło się o awans zawodowy, o rodzinę, o dzień codzienny - dodaje Heinrich - nieumiejętność mówienia «nie» wynikała wprost z braku umiejętności, by na cokolwiek odpowiedzieć zdecydowanym «tak»» (Heinrich 1985: 109).

Portrety pokolenia pomocników artylerii - Schelsky'ego i Heinricha - różnią się oceną moralną przynależących do niego jednostek, jednak w gruncie rzeczy wiele je łączy, gdy chodzi o zaznaczenie najważniejszej cechy tego pokolenia: ontologicznej niepewności siebie i unikania, jak świetnie określił to Heinrich, zarówno rozczarowań, jak i ich braku. Ten pogląd, jak się wydaje, podziela również Heinz Bude, którego książka o „Flakhelfer-Generation” pochodzi z 1987 r. (ważne wydaje się tu, że socjolog z Hamburga pisze swoją książkę w połowie lat 80. XX w., gdy pokolenie '45 zdążyło już osiągnać pierwsze sukcesy i pojawić się

\footnotetext{
${ }^{9}$ Tłumaczenie autorki. W oryginale fragment ten brzmi następująco: ,ich bin geblendet geboren, schaum in den augen/brüllend von wehmut, ohne den himmel zu sehen,/am schwarzen freitag, heute vor dreißig jahren. [...] /horch! /wer ruft grüßgott aus dem schaum?/wer heißt mich hoffen? und warum hoffen?/wer reicht mir die klebrige bruderhand?/loslassen! loslassen! ich bin keiner von euch/ und keiner von uns: ich bin zufällig geboren/unter schäumenden wasserwerfern, zufällig brüllend,/ ehrlich gesagt, allein, ohne brüder, geblendet,/am schwarzen freitag, ein einem rosa bidet".
} 
w niemieckiej sferze publicznej). To tych rozważań należałoby dodać jeszcze jedno spostrzeżenie: dla niemieckiego pokolenia '45 najważniejsze wydaje się zapobieżenie ponownemu stoczeniu się Republiki Federalnej w totalitaryzm i wojnę. Widać to wyraźnie w dyskusjach między członkami tegoż pokolenia, o których pisać będę niżej.

Może się wydawać, że rozważania na temat „ostrożnych, ale odnoszacych sukcesy młodych ludzi” pozostają w niejakim kontraście wobec tego, że do pokolenia '45 należy wiele osób, o których wspominałam wcześniej: aktywnie współtworzących debatę publiczną, zajmujących ważne społecznie pozycje, odgrywających role autorytetów. Jak pogodzić z tym powyższy, socjologiczny obraz „Flakhelfer-Generation”? Jedną z możliwych hipotez może być ta, że kariery takich ludzi, jak Jürgen Habermas, Niklas Luhmann lub Joseph Ratzinger, są w jakiś sposób sprzężone czy też wynikaja z charakterystyki ich pokolenia. Choćby w sensie doboru tematyki prac, a jeszcze bardziej - podejścia do tej tematyki, które zdradza zaznaczaną przeze mnie wyżej obawę przed odwróceniem procesu demokratyzacji. Jak zobaczymy w drugiej części tekstu, ważne dyskusje między przedstawicielami interesującego mnie pokolenia dotyczą utrzymywania stabilności społecznej, stosunku do przeszłości oraz wartości, na których opiera się system społeczny. Heinz Bude używa ciekawego porównania, pisząc, że owe wybitne postacie są niczym soliści orkiestry, którą tworzy szeroko pojęte pokolenie późnych lat 20. XX w. (Bude 1987: 72). Wydaje się, że jest w tym stwierdzeniu wiele racji.

\section{/// Pokolenie rozmawia}

\section{Czym jest socjologia? Czyli „Habermas-Luhmann-Kontroverse”}

Niemiecki dyskurs socjologii teoretycznej został w latach 70. XX w. w dużej mierze zdominowany przez dyskusję między Jürgenem Habermasem a Niklasem Luhmannem. Obaj naukowcy po raz pierwszy zetknęli się, gdy Niklas Luhmann pod koniec lat 60. zastępował na uniwersytecie we Frankfurcie nad Menem Theodora Adorno. Habermas już wówczas należał do najpoważniejszych krytyków przyszłego autora Funkecji religii, nie przeszkodziło to jednak obu naukowcom we wspólnym prowadzeniu seminarium. Owocem współpracy był zapis sporów, które towarzyszyły owym zajęciom: książka Theorie der Gesellschaft oder Sozialtechnologie. Was leistet die Systemforschung? (1971). Co ciekawe, Habermas i Luhmann powołują się w niej na tych samych klasyków - choćby Talcotta Parsonsa i Maxa Webera - jako najważniejszych dla ukształtowania ich myślenia o społeczeństwie. Niezależnie od źródeł inspiracji, dochodzą jednak do zupełnie odmiennych 
wniosków, zwłaszcza gdy idzie o to, czym jest socjologia i co znaczy być socjologiem. Nadają inne znaczenia wspólnie używanym pojęciom, takim jak „system” i „komunikacja”.

Centralnym pytaniem dyskusji, którą od nazwisk obu autorów nazwano „Habermas-Luhmann-Kontroverse”, było to, czy zasadnicza dla myślenia oświeceniowego i niemieckiego idealizmu idea emancypacji przez racjonalne działanie polityczne jest wciąż aktualna. Habermas argumentował, że rewitalizacja ideałów oświecenia i niemieckiego idealizmu jest możliwa, pod warunkiem, że dostosuje się ją do współczesności i wzbogaci o doświadczenia historyczne XX w. Luhmann uważał, że nie jest to możliwe i zarzucał Habermasowi myślenie życzeniowe (Luhmann 1997: 1112).

Prześledźmy, w jaki sposób obaj naukowcy różnili się między sobą w odniesieniu do bardziej szczegółowych zagadnień. Pierwszą sferą, której dotyczyły rozważania Luhmanna i Habermasa, była teoria nauki, ze szczególnym uwzględnieniem socjologii. Habermas, wierny w tym względzie teorii krytycznej, widzi w socjologii krytykę społeczeństwa, a zatem również zobowiązanie moralne, by nie tylko opisywać stany społeczne, lecz również wskazywać drogi poprawy społeczeństwa. Opisywanie społeczeństwa, według Habermasa, musi odbywać się z poziomu krytycznego wobec ideologii, niejako z poziomu wyższej wiedzy (Habermas, Luhmann 1971). Jego najważniejszym przekonaniem jest, że ulepszenie społeczeństwa jest możliwe.

„To tak, jakby istniało jakieś inne, dobre społeczeństwo poza tym, które znamy" - podsumowywał rozważania Habermasa Luhmann (Luhmann 1997: 116). Zarzucal też Habermasowi, że przywiązanie do przestarzałych ideałów uniemożliwia mu znalezienie właściwych rozwiązań i przez to samo jest utopijne. Autor Funkcji religii uważa się wyłącznie za obserwatora społeczeństwa. Socjologia ma być według niego obserwacja, a ściślej: samoobserwacją i samoopisem, dokonywanymi przez społeczeństwo (Habermas, Luhmann 1971). Dopuszczalne jest też pojęcie socjologii jako obserwacii obserwatorów spoleczeństwa (np. wtedy, gdy mamy do czynienia z badaniami masowych mediów). „Musimy społeczeństwo zaakceptować jako rezultat pewnego rodzaju ewolucji” - tłumaczył Luhmann (Luhmann 1997: 117). Za przekonaniami Luhmanna stoi założenie, że ulepszyć można nie społeczeństwo, ale teorię społeczną. Zanim nie będziemy pewni, jak o społeczeństwie należy myśleć, lepiej wstrzymać się z ocenami moralnymi na jego temat (Luhmann 1987: 128).

Kolejne różnice dotyczą rozumienia pojęć. Według Habermasa, w społeczeństwie istnieja „,systemy” - takie choćby, jak gospodarka czy polityka 
- które znacząco różnią się od „ś́wiata przeżywanego” (Lebenswelt), na który składają się np. sfera prywatna, kultura, sfera publiczna. Z kolei Luhmann twierdzi, że systemem jest całe społeczeństwo. W systemie owym wszystko - gospodarka, polityka, media, rodziny, wszystkie społeczne kontakty itd. - są również społecznymi systemami.

Z pojęciem systemu wiąże się rozbieżne rozumienie pojęcia „komunikacji”. Habermasowskie „działanie komunikacyjne” podporządkowane jest typowi racjonalności nakierowanej na wzajemne rozumienie (w przeciwieństwie do działania teleologicznego, regulowanego przez normy, i dramaturgicznego, które rządzą się innymi rodzajami racjonalności). Działanie komunikacyjne charakterystyczne jest dla aktorów społecznych w świecie przeżywanym (Lebenswelt), ale nie w ramach systemów. Z kolei Luhmann twierdzi, że „komunikacja” jest budulcem wszelkich systemów społecznych. Do tego dochodzi jeszcze jedna różnica: teoria Habermasa jest zorientowana na podmiot. Autor Teorii działania komunikacyjnego twierdzi, że komunikować się moga (choć nie musza) ze sobą jednostki. Z kolei Luhmann uważa, że komunikacja nie odbywa się między jednostkami ludzkimi, ale zawsze między systemami. Z tego względu nazywano czasem jego metodę „antyhumanistyczną" (Berghaus 2004). Wreszcie, według Habermasa, działanie komunikacyjne nakierowane jest na wzajemne zrozumienie. Jego celem jest konsensus. Z kolei u Luhmanna komunikacja polega na rozumieniu różnicy między informacją a komunikatem. Analiza naukowa ma polegać na badaniu tej różnicy.

Również Habermas zarzucał Luhmannowi utopijność myślenia. Jego żądanie, by opisać świat w całej swojej złożoności, jest niewykonalne, wręcz bliskie utopii - pisal autor Pryysz̨ości natury ludžkiej (Habermas, Luhmann 1971) i dodawał: „Cała ta teoria jest błędna, choć nie można jej odmówić wysokiej jakości” (Berghaus 2004).

Często uznaje się, że debata między Habermasem a Luhmannem zakończyła się dwiema publikacjami. W 1981 r. Habermas opublikował Teorie działania komunikacyjnego. W 1984 r. ukazała się ważna książka Luhmanna - Soziale Systeme. Niektórzy badacze twierdzą jednak, że dyskusja między dwoma socjologami trwała aż do śmierci Luhmanna w 1998 r., ponieważ przez następne kilkanaście lat obaj chętnie odwoływali się zarówno do siebie nawzajem, jak i do odbytej na przełomie lat 60. i 70. XX w. debaty (Kjaer 2006).

Jak można zinterpretować dyskusję między Habermasem a Luhmannem w kategoriach pokolenia „Flakhelfer”? Przywołajmy dłuższy fragment z książki Heinza Budego, który wprost interpretuje dyskusję dwóch naukowców jako wyraz przynależności do pokolenia '45: 
$\mathrm{Na}$ pierwszy rzut oka funkcjonalna teoria systemów Luhmanna może być interpretowana jako apologia „funkcjonalnej solidności”, o której pisze Schelsky. Z kolei teoria krytyczna w wykonaniu Habermasa może być odczytywana jako protest przeciwko funkcjonalnemu dopasowaniu jednostek w systemie społecznym. [...] Obaj socjologowie dają różne odpowiedzi na doświadczenie rozczarowania rokiem 1945. Odpowiedź Luhmanna to konstrukcja teorii systemów społecznych, która rozumie społeczeństwo jako samoregulujący się system, w który jednostki są niejako wbudowane, podczas gdy odpowiedź Habermasa to koncepcja teorii społecznej, przedstawiająca kontrfaktyczną możliwość moralności zorientowanej na zrozumienie. Habermas pragnie w ten sposób uratować społeczeństwo. Pierwsza teoria opowiadałaby się za redukcja, druga - za rekonstrukcją po rozdarciu, jakim był rok 1945 (Bude 1987: 200-201).

Zdaniem Budego, istotna jest też, zarówno w podejściu Habermasa, jak i Luhmanna, diagnoza „ontologicznej niepewności” i reakcja na nią: Wszystko, co jest, może wyglądać też zupełnie inaczej. Ta „ontologiczna niepewność", powiedziałby pewnie Luhmann, jest być może trudna do wytrzymania, jednak to dzięki niej pojawiają się w strukturze naszej rzeczywistości ciagle nowe elementy. To z kolei prowadzi do takiego rodzaju teorii, która to, co jest prawdziwe, stawia w wattpliwość wobec tego, co jest możliwe. Inaczej u Habermasa. Jego wersję teorii krytycznej można rozumieć jako pewnego rodzaju odejście od Adorno i Horkheimera. Negatywnej krytyce Dialektyki Oświecenia przeciwstawia on trud ustanowienia moralnych podstaw krytyki społeczeństwa. Krytykę, powiedzmy, ontologicznie niepewna, pragnie ustawić na pewniejszych podstawach, ugruntowując jej negatywność na tym, co pozytywne. To z kolei znajduje on w ewolucji moralności w historii ludzkiej, ze względu na którą przesuwa moralność uniwersalną społeczeństwa mieszczańskiego na wyższy poziom. Szukając fundamentu dla swojej krytyki, Habermas dochodzi do afirmacji istniejącej już struktury. Dla Habermasa „ontologiczna niepewność” jest sytuacją braku, z którą należy walczyć. Dla Luhmanna jest to kondycja, którą trzeba znieść. Wygląda to tak, jakby za apologią „funkcjonalnej solidności” stała akceptacja „ontologicznej niepewności”, za krytyką zaś „funkcjonalnej solidności” - od owej niepewności odejście. Porównanie to może udać sięjednak tylko wówczas, gdy uznamy, że „funkcjonalna solidność” i „ontologicznaniepewność” to dwie twarze tego samego zjawiska (Bude 1987: 202) ${ }^{10}$.

\footnotetext{
${ }^{10}$ Ciekawym uzupełnieniem rozważań Budego są dwa cytaty, podawane przez niego w przypisie. Pierwszy to fragment z rozmowy z Niklasem Luhmannem: „Proszę pomyśleć o sytuacji z 1945 r., jak ją przeżywa 17-latek. Wcześniej wszystko wydawało się mieć porządek i później również. Wszystko było inaczej i wszystko było tak samo. Wcześniej miało się problemy z reżimem, a później nie było tak, jak byśmy się tego spodziewali. Prawdopodobnie to dlatego studia prawnicze stały się tak ważne dla mojego myślenia. Przed 1945 r. miało się nadzieję, że po upadku aparatu przemocy wszystko samo z siebie ustawiłoby się we właściwym porządku. Jednak pierwszą rzeczą, której doświadczyłem
} 


\section{„Dwaj papieże”}

W dniu 19 stycznia 2004 r. odbyło się w Monachium wyjątkowe spotkanie. „Był to wieczór, jakiego niemiecki świat akademicki jeszcze nie widział” (Kissler 2005: 174). Wśród słuchaczy znaleźli się sławni niemieccy myśliciele, m.in. teologowie Johann Baptist Metz i Wolfhart Pannenberg oraz filozof Robert Spaemann. Przyszli, by wysłuchać wystąpień „naczelnego myśliciela Republiki Federalnej Niemiec" - jak mawiano o Jürgenie Habermasie - i „katolickiego Habermasa z Rzymu”, jak nazywano przyszłego papieża, a wtedy prefekta Kongregacji Nauki Wiary Josepha Ratzingera (Kissler 2005: 147).

Jak doszło do tego spotkania? Jego historia sięga mowy dziękczynnej, którą Habermas wygłosił we Frankfurcie 11 września 2001 r., odbierając Nagrodę Pokojową Księgarzy Niemieckich. Filozof, który wielokrotnie wcześniej mówił o sobie jako o człowieku „religijnie niemuzykalnym", ku zdziwieniu wielu osób wypełnił swoje przemówienie nawiązaniami do religii. Społeczeństwo współczesne powinno, mimo „rozdziału religii od państwa” oraz „napięcia między zsekularyzowanym społeczeństwem a religia", uznać przekonania religijne za coś więcej niż tylko relikty przeszłości. Jako podstawa zachodniej moralności, religia jest - przekonywal - „wyzwaniem poznawczym”, stojącym przed filozofia. Zachęcił też wierzacych, by „tłumaczyli swoje przekonania religijne na język świecki”, aby umożliwić lepsze porozumienie między wierzącymi i niewierzącymi (Horster 2006: 42). Mowa ta została uznana za rękawicę rzuconą Kościołowi (Habermas, Ratzinger 2005: 10), jednak początkowo nie znalazła odpowiedzi. Aż do roku 2004, gdy Habermas i Ratzinger spotkali się na wydziale teologicznym Uniwersytetu Ludwiga Maksymiliana w Monachium, dwaj

\footnotetext{
w amerykańskiej niewoli, było to, że zabrano mi zegarek i sprano na kwaśne jabłko. Było zupełnie inaczej, niż wcześniej sobie wyobrażałem. I szybko można się było zorientować, że porównanie między systemami politycznymi nie mogło przebiegać na osi «dobry - zły». Trzeba było oceniać konkretne postacie $\mathrm{w}$ ich ograniczonej rzeczywistości. Nie chcę przez to w żadnym wypadku powiedzieć, że uważam epokę nazistowską i czas po 1945 r. za równowartościowe. Ale po 1945 r. byłem po prostu rozczarowany” (wywiad z Niklasem Luhmanem we Frankfurter Rundschau, „Zeit und Bild”, 27 kwietnia 1985, s. 3). Drugi fragment pochodzi z rozmowy z Habermasem: „Nie mam zaufania do otoczenia, ale też nie jestem nastawiony w taki sposób, bym chciał zamienić zadowalający porządek w chaos. W ogóle nie ma niczego, do czego miałbym stosunek nieambiwalentny, może poza krótkimi momentami. Ma to związek z bardzo osobistymi doświadczeniami, o których nie chciałbym opowiadać albo których nie chciałbym krytykować - np. z połączeniem wielkich wydarzeń i mojego własnego dojrzewania w 1945 r. Ambiwalencja cechuje mnie także dlatego, że mam wrażenie, iż w racjonalnym społeczeństwie, w którym się wychowałem i w którym teraz żyję, jest coś głęboko nie tak. Z drugiej strony, nie mam wątpliwości, że od 1945 r. wiele rzeczy zmieniło się na lepsze" (rozmowa Axela Honnetha z Jürgenem Habermasem, „Ästetik und Kommunikation” 1981, nr 12, s. 152).
} 
myśliciele, którzy - mimo że ich życiorysy były niemal analogiczne - nigdy wcześniej osobiście się nie zetknęli.

Główną osią debaty było poruszone przez Habermasa podczas mowy dziękczynnej we Frankfurcie pytanie, czy świeckie państwo konstytucyjne potrafi z własnych zasobów odnawiać normatywne założenia, na których się opiera. Habermas, jako gość teologów, wygłosił swoją mowę pierwszy. Wyraził w niej przypuszczenie, że zasoby te znajdują się poza państwem konstytucyjnym jako takim i pochodza $\mathrm{z}$ religijnych, a w każdym razie kolektywnie wiążących tradycji (Habermas, Ratzinger 2005: 16).

Następnie Habermas analizował problem zasobów z dwóch punktów widzenia. Po pierwsze, z poznawczego, wiążąc go z pytaniem, czy możliwa jest świecka (to jest niereligijna i niemetafizyczna) legitymizacja władzy politycznej, korzystającej wyłącznie z prawa pozytywnego. Jeśli nawet tak, odpowiada Habermas, to wciąż pozostaje wątpliwość, czy światopoglądowo pluralistyczna wspólnota będzie możliwa do ustabilizowania wyłącznie dzięki kombinacji racjonalnego prawa i postępowania. Dalej - jeślibyśmy nawet rozwiali tę wątpliwość - szybko okaże się, że społeczeństwa liberalne nie mogą funkcjonować bez zasady solidarności między ich członkami. Zatem „całkowita i wykolejona” sekularyzacja może doprowadzić nawet do zniszczenia społeczeństwa (Habermas, Ratzinger 2005: 17).

W związku z powyższym Habermas proponuje, by rozumieć kulturową i społeczną sekularyzację jako obustronny proces uczenia się, który tradycje oświecenia - podobnie jak nauki religijne - wykorzystuje do refleksji nad kształtem współczesnego społeczeństwa. Wzajemne przenikanie się chrześcijaństwa i greckiej metafizyki wpłynęło nie tylko na kształt teologii chrześcijańskiej - uważa Habermas. Przyniosło ono także przyswojenie przez filozofię treści chrześcijańskich. Było tak szczególnie, gdy chodziło o tematy związane z moralnością: odpowiedzialność, autonomię, uzasadnienie moralne czynów, historię, pamięć, nowy początek, innowację i powrót, emancypację, spełnienie itd. Treści te zostały przez filozofię, co prawda, przekształcone, ale nie zniszczone. Przekształcenie stworzenia człowieka na podobieństwo Boże w równą i konieczną do szanowania ludzką godność jest jednym z dobrych przykładów tego procesu. Ten zabieg pozwala - według Habermasa - przenosić pojęcia i zasady charakterystyczne dla Biblii również do innych grup, do szerszej publiczności. Z tego powodu współczesne państwo musi być świadome różnych zasad, które czerpać można z różnorodnych, należących do niego podkultur i podspołeczności (Habermas, Ratzinger 2005: 31). Wynika z tego nie tylko - pisze Habermas - że państwo powinno uznawać istnienie grup religijnych. Państwo zobowiązane jest również zdawać sobie sprawę 
z tego, że to one są w naszym „postsekularnym” świecie nośnikami treści, reprodukujących to państwo samo w sobie. Choć zatem dziela nas przekonania - argumentuje autor Faktyczności i obowiazywania - to zarówno wierzacy, jak i zsekularyzowani obywatele moga się porozumieć, jeśli pojma, że na poziomie poznawczym bardzo wiele ich łaczzy (Habermas, Ratzinger 2005: 33). Gdy chodzi natomiast o konieczne nastawienie religii do państwa świeckiego, Habermas argumentuje, że każda religia posiada własny obraz świata oraz doktrynę, zgodnie z którą wierzacy uważał kiedyś, że tylko jego religia tłumaczy świat. Wraz z sekularyzacją wiedzy, neutralizacja przemocy państwowej oraz rozwojem wolności wyznania religie musiały pożegnać się z roszczeniem do dysponowania prawdą absolutną na temat świata. A więc

rozumienie tolerancji w liberalnych demokratycznych państwach konstytucyjnych nie ogranicza się tylko do tego, by wierzący mogli być przyjęci w kręgi niewierzących i by dbało o nich państwo. Również od drugiej strony wymaga się tego samego (Habermas, Ratzinger 2005: 35).

Przejdźmy teraz do przemówienia Josepha Ratzingera. Prefekt Kongregacji Nauki Wiary zwrócił uwagę, że w charakterystycznym dla naszych czasów przyspieszeniu rozwoju cywilizacyjnego najważniejsze są trzy czynniki. Pierwszy z nich to rozwój społeczeństwa światowego, w którym polityczne, gospodarcze i kulturalne potęgi w coraz większym stopniu stykaja się ze sobą i są od siebie nawzajem zależne. Drugi - to rozwój ludzkich możliwości, ludzkiej mocy budowania i mocy niszczenia, od którego niedaleko do pytania o prawne i etyczne sposoby kontrolowania tych mocy. Najważniejszym i najpilniejszym pytaniem współczesności, według Ratzingera, jest, w jaki sposób różne wspólnoty maja współistnieć. Jako trzeci czynnik autor Wielości religii $i$ jednego pryymierza wymienia fakt, że we wzajemnym przenikaniu się kultur tylko z największą trudnością możemy mówić dziś o etycznych pewnikach. Co więcej, dzisiejszy świat w wielkiej mierze doświadczył upadku moralnych pewników w ogóle (Habermas, Ratzinger 2005: 40).

Trudności tych nie może rozwiązać nauka - argumentował Ratzinger - ponieważ odnawianie świadomości etycznej nie jest produktem postępowania badawczego. Poza tym, nauka sama w wielkiej mierze przyczyniła się do upadku moralnych pewników. Dlatego szczególna odpowiedzialność spoczywa na filozofii, która w krytyczny sposób może towarzyszyć rozwojowi nauki, prześwietlając jej działanie i uwrażliwiając ją na bogactwo natury ludzkiej.

Ratzinger w dużej mierze zgadza się z Habermasem w tym, jaka rola powinna przypaść religii i filozofii w społeczeństwie postsekularnym - 
szczególnie, gdy chodzi o gotowość do wzajemnego uczenia się oraz samoograniczania. Dodaje jednak do wniosków autora Teorii dz̨iałania komunikacyjnego dwa zastrzeżenia.

Po pierwsze, religii nie są obce niebezpieczne patologie, które moga przesłaniać „boskie światło rozumu” (Habermas, Ratzinger 2005: 56). Religia musi się przed nimi wciąż od nowa strzec, by nie dopuścić ich do swego sedna. Istnieja jednak również patologie rozumu, szczególnie pycha, bybris. Ta ostatnia nie tylko nie jest mniej groźna, ale może doprowadzić do jeszcze większego zniszczenia niż patologie religii. $\mathrm{W}$ historii $\mathrm{XX}$ w. mieliśmy tego przykłady: bombę atomową, Auschwitz. Musimy więc zdawać sobie sprawę z konieczności korelacji między religia a rozumem, które nawzajem wzywają się do oczyszczania i uzdrawiania, nawzajem się potrzebują i nawzajem muszą się uznać. Jeśli te dwie dziedziny całkowicie się wyemancypują, mogą stać się siłami niszczycielskimi.

Po drugie, powyższą zasadę należy skonkretyzować w kontekście międzykulturowym.

Bez watpienia najważniejszymi partnerami w tej korelacji są wiara chrześcijańska i zachodnia zsekularyzowana racjonalność. Można i trzeba to stwierdzić bez fałszywego eurocentryzmu. To jednak nie oznacza, że inne kultury można odsunąć jako quantite négligeable. To oznaczałoby kolejna - zachodnia - bybris, za która słono przyszłoby nam zapłacić i za która, w rzeczywistości, płacimy już dziś. A zatem także korelacja z innymi kulturami jest dla nas zasadnicza (Habermas, Ratzinger 2005: 42).

Również dyskusję Habermasa i Ratzingera - między którymi, jak widać, znacznie więcej jest punktów wspólnych niż w pierwszej chwili można byłoby się spodziewać - można zinterpretować w kategoriach przynależności do „Flakhelfer-Generation”. Odpowiedź Habermasa na pytanie o odnawianie się państwa konstytucyjnego z własnych zasobów jest przesunięciem jego dotychczasowych rozważań, poświęconych budowaniu komunikacji i konsensusu w obrębie jednego społeczeństwa, na wyższy poziom porozumienia między grupami religijnymi i świeckimi pluralistycznego społeczeństwa nowoczesności. Tym razem, by użyć cytowanych wcześniej słów Heinza Budego, Habermas nie chce „uratować społeczeństwa" rozumianego jako jednonarodowe. Gdy chodzi o społeczeństwo europejskie, Habermas przez lata należał do gorących zwolenników budowania tożsamości niemieckiej, a także europejskiej, na świadomości niemieckiej winy. Było to szczególnie wyraźne podczas Historikerstreit. Jednak dziś, zdaniem Habermasa, myślenie to odchodzi 
już do przeszłości ${ }^{11}$. Dziś należy iść o krok dalej, dostrzegając, że przyczyną najpoważniejszych konfliktów w społeczeństwie europejskim początku XXI w. będą konflikty między grupami świeckimi a religijnymi. Owo nowoczesne europejskie społeczeństwo można, jego zdaniem, uratować dzięki wypracowaniu wewnętrznego konsensusu, by ustrzec je przed kolejnymi, możliwymi rozczarowaniami. Również Ratzinger dostrzega, że mierzymy się dziś przede wszystkim ze społeczeństwem globalnym, a nie społeczeństwami narodowymi. Jego odpowiedź można rozumieć jako otworzenie się tego przywiązanego do czystości doktryny chrześcijańskiej myśliciela nie tylko na naukę, ale i na ostrożny ekumenizm. Logika wywodu przyszłego papieża opiera się na podobnej do Habermasowskiej myśli: nawet jeśli do naszej współczesności mamy stosunek w dużej mierze ambiwalentny, nie warto jej odrzucać. Znacznie lepszym rozwiązaniem jest ostrożna próba pogłębienia w niej tego, co uważamy za pozytywne, i krytycznego zauważenia tych elementów, które mogą mieć w dłuższej perspektywie negatywne konsekwencje. To właśnie owa ostrożność wydaje się czynnikiem najbardziej wiążącym Ratzingera z niemieckim pokoleniem '45.

\section{/// Podsumowanie}

Zgodnie z obowiązującym w Republice Federalnej prawem, zdolność do odpowiadania za swoje czyny wobec sądu osiagamy w najbardziej ograniczonym zakresie już w 14 roku życia - przypomina Bernhard Schlink. Z punktu widzenia prawa i arytmetyki, spośród współcześnie żyjących Niemców za świadków tego, co działo się przed 9 maja 1945 r., można zatem uznać wyłącznie tych, którzy wówczas mieli co najmniej 14 lat. Biorąc pod uwagę upływ czasu, Schlink ocenia, że dziś, w 2010 r., grupa ta stanowi zaledwie 7\% populacji Republiki Federalnej.

\footnotetext{
${ }^{11}$ Warto w tym kontekście zacytować następująca wypowiedź Habermasa: „Poskromienie Niemców było jednym z podstawowych powodów, dla których powstała Unia. Cel był jasny: już nigdy suwerennej, niezależnej polityki niemieckiej. Szczególnie zagranicznej, bo nigdy nie doprowadziła ona do niczego dobrego. I ja sam przez całe moje długie życie starałem się opierać moje poglądy i działania na zasadzie ograniczonego zaufania, ale w stosunku do nas samych, do Niemców, a nie do innych. Niech pani zwróci jednak uwagę, że sytuacja zmieniła się diametralnie od połowy XX stulecia, kiedy zaczynaliśmy budować Unię. Dziś inne są powody, dla których konieczna jest silna Unia Europejska. O trzech najważniejszych mówiłem już wcześniej, do pozostałych zaliczyć należy również zmiany klimatyczne, potrzebę dzielenia kurczących się zasobów energetycznych, kryzysy gospodarcze, których, jak w wypadku ostatniego kryzysu na Wall Street, nie da się przewidzieć. Takie problemy należy rozwiązywać razem, a nie korzystając ze złego przykładu, który w ostatnich latach zwykły dawać nam Stany Zjednoczone. I nie tylko one, bo nie brakuje egoistycznych i rozpychających się łokciami rządów w samej Europie" (Europe ogarnia śmiertelny beswetad, z J. Habermasem rozmawia Karolina Wigura, Tygodnik Idei „Europa”, 27 września 2008, s. 3).
} 
W 2025 r. zaś nie będzie już żył ani jeden jej przedstawiciel (Schlink 2007: 12).

Te słowa można odnieść do niemieckiego pokolenia '45. Osoby zaliczające się do tego wyjątkowego pokolenia należą obecnie do najstarszych w Republice Federalnej. Dziś ich ostrożna, a jednak barwna działalność wpisuje się w pokoleniowy krajobraz Niemiec. Jednak nawet za kilkanaście lat, gdy nie będą piastowali już ważnych społecznych funkcji, a rolę autorytetów przejmą w Niemczech młodsi od nich przedstawiciele pokolenia '68, nie zmieni się jedno: całe to pokolenie było jednym z najważniejszych - najpierw dla zbudowania, a następnie dla rozwoju modelu nowoczesnej Republiki Federalnej. Z kolei najbardziej znane spośród niego osoby pełniły, jak można wywnioskować z powyższych rekonstrukcji wewnątrzpokoleniowych debat, rolę „wyrazicieli” przekonań tej generacji. Ważna jest konstatacja, że, nie znając historii pokolenia '45, właściwie nie sposób ani zrozumieć dobrze współczesnych Niemiec, ani też pojąć, dlaczego jego przedstawiciele zachowywali się właśnie tak, a nie inaczej. Znajomość szczególnych warunków biograficznych, w których dojrzewali, pozwala pojąć w nowej perspektywie np. konflikty między nimi a pokoleniem późniejszym. Dobrym przykładem jest tu choćby spór między Jürgenem Habermasem a przedstawicielem pokolenia '68 Peterem Sloterdijkiem po opublikowaniu przez tego ostatniego książki Regeln für den Menschenpark w 1999 r. ${ }^{12}$

$\mathrm{Na}$ koniec warto również dodać uwage bardziej ogólną. Historia niemieckiego pokolenia '45 może przynosić ciekawą perspektywę również dla czytelnika polskiego. Niewykluczone, że reakcję rozczarowania „Flakhelfer-Generation” można z powodzeniem porównywać z reakcjami pokolenia, które wchodziło w dorosłość w 1989 r. w Polsce. Ciekawe byłoby również porównanie retoryki wewnątrz- i międzypokoleniowej w Polsce po 1989 r. w odniesieniu do doświadczeń kolejnych pokoleń niemieckich. Cytowany wcześniej Schelsky, opisując „Flakhelfer-Generation”, argumentował, że jego charakter, być może

\footnotetext{
${ }^{12}$ Sloterdijk, naruszając typową dla niemieckiej debaty publicznej po 1945 r. daleko idącą ostrożność w wypowiadaniu się na tematy genetycznych manipulacji i eugeniki, apelował w niej o odważną dyskusję w kwestii regulacji „biologiczno-kulturowej” reprodukcji. Habermas zarzucił Sloterdijkowi faszyzm, wytykając mu użycie kojarzącej się z nazizmem retoryki, a przede wszystkim słów Zücbtung (hodowla, chów) i Selektion (selekcja). Sloterdijk odpowiedział listem otwartym do Habermasa, w którym twierdził, że filozof „krytykuje go za jego plecami” i prezentuje typ humanizmu, który Sloterdijk uznał za martwy (patrz np.: Karacs, Imre. Anger as philosopher revives vocabulary of Third Reich. „The Independent”, 30 września 1999). Ostrożność i rozsierdzenie Habermasa na młodszego, znacznie dalej posuwającego się w swoich rozważaniach kolegę, można interpretować jako element typowego dla tego filozofa - ale też dla jego pokolenia - nastawienia do rzeczywistości.
} 
w równej mierze jak z osobistych doświadczeń, wynika z szerzej rozumianej epoki, w której urodzonym w późnych latach 20. XX w. przyszło dorastać - epoki nowoczesności. Jednak, śledząc biografie rówieśników Habermasa, Luhmanna i Ratzingera, można odnieść wrażenie, że dzielone przez nich doświadczenia życia w totalitarnym ustroju, wojny i powojennego przełomu moga być ważniejsze niż owa szeroko zdefiniowana epoka. Dlatego wyniki badań porównawczych między niemieckim pokoleniem '45 a polskim pokoleniem wchodzacym w dorosłość zaraz po 1989 r. mogłyby okazać się niezmiernie interesujące.

Bibliografia:

/// Augstein, Rudolf. 1995. „Historikerstreit”. Die Dokumentation der Kontroverse um die Einqigartigkeit der nationalsozialistischen Judenvernichtung. München: Piper.

/// Baumert, Gerhard. 1952. Jugend der Nachkriegszeit. Lebensverbältnisse und Reaktionsweisen. Darmstadt: Roether.

/// Berghaus, Margot. 2004. Lubmann leicht gemacht. Eine Einführung in die Systemtheorie. Wyd. 2, popr. Köln-Weimar-Wien: Böhlau.

/// Bude, Heinz. 1987. Deutsche Karrieren. Lebenskonstruktionen sozialer Aufsteiger aus der Flakhelfer-Generation. Frankfurt am Main: Suhrkamp.

/// Busche, Jürgen. 2006. Hat Habermas die Wabrheit verschluckt? „Cicero”, nr 11.

/// Enzensberger, Hans Magnus. 1960. Landessprache. Frankfurt am Main: Suhrkamp.

/// Fest, Joachim. 1983. Erziehung zur Skepsis. Gedanken aus Anlass einer Selbstvorstellung. „Neue Sammlung” 23, s. 334-336.

/// Fest, Joachim. 2006. Ich nicht. Erinnerungen an eine Kindheit und Jugend. Reinbek bei Hamburg: Rowohlt.

/// Habermas, Jürgen. 1981. Kleine Politische Schriften I-IV. Frankfurt am Main: Suhrkamp.

/// Habermas, Jürgen. 1999. Racjonalność driatania a racjonalność spoteczna. Tłum. Andrzej Maciej Kaniowski. Warszawa: Wydawnictwo Naukowe PWN.

/// Habermas, Jürgen. 2006. Antwort dem Busche. „Cicero”, nr 12.

/// Habermas, Jürgen, Luhmann, Niklas. 1971. Theorie der Gesellschaft oder Sozialtechnologie - was leistet die Systemforschung? Frankfurt am Main: Suhrkamp. 
/// Habermas, Jürgen, Ratzinger, Joseph. 2005. Dialektik der Säkularisierung. Über Vernunft und Religion. Freiburg im Breisgau: Herder.

/// Horster, Detlef. 2006. Jürgen Habermas und der Papst. Glauben und Vernunft, Gerechtigkeit und Nächstenliebe im säkularen Staat. Bielefeld: transcript.

/// Jabłkowska, Joanna, Żyliński, Leszek. 2008. O kondycji Niemiec. Tożsamość niemiecka w debatach intelektualistów po 1945 roku. Poznań: Wydawnictwo Poznańskie.

/// Kissler, Alexander. 2005. Der deutsche Papst. Benedikt XVI. und seine schwierige Heimat. Freiburg: Herder.

/// Kjaer, Poul. 2006. Systems in Context. On the outcome of the Habermas/ Lubmann debate. „ANCILLA IURIS”, nr 66, s. 66-77.

/// Kuhr, Irma. 1952. Schule und Jugend in einer ausgebombten Stadt. Darmstadt: Roether.

/// Luhmann, Niklas. 1987. Soziale Systeme. Grundriß einer allgemeinen Theorie. Frankfurt am Main: Suhrkamp.

/// Luhmann, Niklas. 1997. Die Gesellschaft der Gesellschaft. Frankfurt am Main: Suhrkamp.

/// Mannheim, Karl. 1964. Das Problem der Generationen. W: Wissenssoziologie. Berlin: Neuwied.

/// Pinzani, Aleksandro. 2007. Jürgen Habermas. München: Verlag C.H. Beck. /// Rathgeb, Eberhard. 2005. Die engagierte Nation. Deutsche Debatten 1945-2005. München: Carl Hanser Verlag.

/// Schätz, Ludwig. 1974. Schüler-Soldaten. Die Geschichte der Luftwaffenhelfer im Zweiten Weltkrieg. Darmstadt.

/// Schelsky, Helmut. 1957. Die skeptische Generation. Eine Soziologie der deutschen Jugend. Düsseldorf: Diederichs.

/// Schlink, Bernhard. 2007. Vergangenheitsschuld. Beiträge zu einem deutschen Thema. Zürich: Diogenes.

/// Schmid, Hans Bernhard. 2000. Subjekt. System. Diskurs. Dordrecht: Kluwer Academic Publishers.

/// Schmidbauer, Wolfgang. 2009. Ein Land-drei Generationen. Psychogramm der Bundesrepublik. Freiburg im Breisgau: Herder.

/// Schörken, Rolf. 1985. Luftwaffenhelfer und Drittes Reich. Stuttgart: Klett-Cotta.

/// Spranger, Eduard. 1947. Verstrickung und Ausweg. Ein Wort über die Jugend. Konstanz: Südverlag. 
/// Suchende Jugend. Jugend schreibt - Ältere antworten. Mit Geleitwort von Dorothee Dovifat, Gilbert Ziebura und Liselotte Müller. 1948. Berlin: Union-Verlag.

/// Ustorf, Anne-Ev. 2008. Wir Kinder der Kriegskinder. Die Generation im Schatten des Zweiten Weltkriegs. Freiburg im Breisgau: Herder.

/// Wehler, Hans-Ulrich. 2006. Habermas hat nichts verscbluckt. „Die Zeit”, nr 45, 2 listopada 2006; http://www.zeit.de/2006/45/Habermas_hat_ nichts_verschluckt; dostęp: 12 października 2011 r.

/// Wenzel, Uwe Justus. Verscbluckte Geschicbte. Eine Anekdote über Jürgen Habermas wird aufgewärmt. „Neue Zürcher Zeitung”, 28 października 2006; http://www.nzz.ch/2006/10/28/fe/articleELXIL.html; dostęp: 12 października $2011 \mathrm{r}$.

/// Weyrauch, Wolfgang (ed.). 1989. Tausend Gramm. Reinbek: Rowohlt.

\section{/// Abstrakt}

Artykuł poświęcony jest charakterystyce przykładowych sporów, prowadzonych przez trzech przedstawicieli tzw. pokolenia pomocników artylerii („Flakhelfer-Generation”): Jürgena Habermasa, Niklasa Luhmanna i Josepha Ratzingera. Na pierwszą część artykułu składa się charakterystyka pokolenia, z którego wywodzą się owi trzej intelektualiści. Następnie autorka przechodzi do rekonstrukcji dwóch dyskusji, które odbyły się między tymi trzema postaciami. Jest to, po pierwsze, dyskusja między Jürgenem Habermasem a Niklasem Luhmannem o naturze poznania socjologicznego, z której wnioski zostały zawarte przede wszystkim w książce Theorie der Gesellschaft oder Sozialtechnologie - was leistet die Systemforschung?, po drugie zaś dyskusja między Jürgenem Habermasem a Josephem Ratzingerem o roli religii we współczesnym świecie, której zapis znalazł się w książce Dialektik der Säkularisierung. Über Vernunft und Religion. W obu przypadkach autorka wskazuje, które wątki dyskusji mogły być uwarunkowane przynależnością jej uczestników do „FlakhelferGeneration".

Słowa kluczowe:

Flakhelfer-Generation, Jürgen Habermas, Joseph Ratzinger, Niklas Luhmann, intelektualna historia Niemiec 


\section{/// Abstract:}

Flakhelfer-Generation. Habermas, Ratzinger, Luhmann and German debates

The paper characterizes selected discussions between three representants of the so-called Luftwaffe-assistant-generation (Flakhelfer-Generation, Luftwaffenhelfer generation): Jürgen Habermas, Niklas Luhmann and Joseph Ratzinger. The first part of the paper deals with the characteristics of the generation, from which those three intellectuals come. Afterwards two discussions between them are described. Firstly, discussion between Jürgen Habermas and Niklas Luhmann about the nature of sociological epistemology. The most important conclusions of this discussion have been gathered in the book Theorie der Gesellschaft oder Sozialtechnologie - was leistet die Systemforschung? Secondly, a discussion between Jürgen Habermas and Joseph Ratzinger about the role of religion in modern world is reconstructed. This discussion is mostly to be found in the book Dialektik der Säkularisierung. Über Vernunft und Religion. The author points out in every part, which details of the discussion are typical for the „Flakhelfer-Generation”.

Keywords:

Flakhelfer-Generation, Jürgen Habermas, Joseph Ratzinger, Niklas Luhmann, German intellectual history 